\title{
Synthesis of Betulinic Acid Derivatives as Entry Inhibitors against HIV-1 and Bevirimat-Resistant HIV-1 Variants
}

\author{
Zhao Danga ${ }^{a}$ Keduo Qian ${ }^{b}$, Phong Ho ${ }^{a}$, Lei Zhua ${ }^{a}$ Kuo-Hsiung Lee ${ }^{b, c}$, Li Huang ${ }^{a},{ }^{\star}$, and Chin- \\ Ho Chen ${ }^{\mathrm{a}}$, \\ aSurgical Science, Department of Surgery, Duke University Medical Center, Durham, North \\ Carolina 27710, United States \\ bNatural Products Research Laboratories, Eshelman School of Pharmacy, University of North \\ Carolina, Chapel Hill, North Carolina 27599, United States \\ ${ }^{\circ}$ Chinese Medicine Research and Development Center, China Medical University and Hospital, \\ Taichung, Taiwan
}

\begin{abstract}
Betulinic acid derivatives modified at the $\mathrm{C} 28$ position are HIV-1entry inhibitors such as compound A43D; however, modified at the $\mathrm{C} 3$ position instead of $\mathrm{C} 28$ give HIV-1 maturation inhibitor such as bevirimat. Bevirimat exhibited promising pharmacokinetic profiles in clinical trials, but its effectiveness was compromised by the high baseline drug resistance of HIV-1 variants with polymorphism in the putative drug binding site. In an effort to determine whether the viruses with bevirimat resistant polymorphism also altered their sensitivities to the betulinic acid derivatives that inhibit HIV-1 entry, a series of new betulinic acid entry inhibitors were synthesized and tested for their activities against HIV-1 NL4-3 and NL4-3 variants resistant to bevirimat. The results show that the bevirimat resistant viruses were approximately 5 - to 10 -fold more sensitive to three new glutamine ester derivatives $(\mathbf{1 3}, \mathbf{1 5}$ and 38) and A43D in an HIV-1 multi-cycle replication assay. In contrast, the wild type NL4-3 and the bevirimat resistant variants were equally sensitive to the HIV-1 RT inhibitor AZT. In addition, these three new compounds markedly improved microsomal stability compared to A43D.
\end{abstract}

\section{Keywords}

HIV-1; Entry inhibitor; Maturation inhibitor; Betulinic acid; Berivimat; Berivimat-resistance

The HIV-1 life cycle is initiated by a multi-step entry of HIV into the target cell that involves interactions of HIV-1 gp120 to the cell surface receptor CD4 and co-receptors CXCR4 or CCR5 (1). Binding of gp120 to the cellular receptors triggers conformational changes in HIV-1 envelope glycoproteins that allow HIV-1 to enter the cells (2).

\footnotetext{
(C) 2012 Elsevier Ltd. All rights reserved.

*To whom correspondence should be addressed. L. Huang, Tel.: 919-684-2952. Fax: 919-684-3878. lihuang@ duke.edu. C. H. Chen, Department of Surgery, Box 2926, Duke University Medical Center, Durham, NC 27710-2926, U.S.A. Tel.: 919-684-3819; Fax: 919-684-3878; chc@duke.edu.

Supplementary data: Methods of organic synthesis, anti-HIV assay, and metabolic stability study as well as spectroscopic data of synthesized compounds were included. The supplementary data are available in the online version.

Publisher's Disclaimer: This is a PDF file of an unedited manuscript that has been accepted for publication. As a service to our customers we are providing this early version of the manuscript. The manuscript will undergo copyediting, typesetting, and review of the resulting proof before it is published in its final citable form. Please note that during the production process errors may be discovered which could affect the content, and all legal disclaimers that apply to the journal pertain.
} 
Interference at the various steps of HIV entry has been proved to be a successful strategy for drug development of anti-HIV therapy. Examples of drugs that target HIV entry include the gp41 fusion inhibitor enfuvirtide and the CCR5 receptor antagonist maraviroc $(1,3,4)$. Enfuvirtide has high potency and broad spectrum in HIV inhibition but as a peptide, has limited oral bioavailability. Maraviroc is very effective against HIV-1 R5 viruses that use the CCR5 co-receptor for entry, but not X4 strains that use CXCR4 for entry. In mid 90s, a betulinic acid (BA) derivative was reported with potent anti-HIV-1 activity in the early stage of HIV life cycle (5). It has been shown that BA derivatives with side chain modification at the $\mathrm{C} 28$ position inhibited viral entry by blocking the conformational change of HIV gp120 during the process of HIV entry (6,7). Further study suggested that these compounds targeted the V3 region of HIV gp120, preventing the subsequent conformational changes in HIV-1 gp41 in HIV entry (8). Among a series of C28 modified BA derivatives, compound A43D exhibited the most potent anti-HIV-1 entry activity (9).

A43D was effective against a variety of HIV subtypes and displayed the strongest inhibition to the clade C HIV-1 strains (8). However, as shown in the results section, the microsomal stability of A43D was poor when it was compared to bevirimat (BVM). BMV is a BA derivative that targets HIV-1 maturation instead of entry by blocking the processing of Gag precursor protein at a specific step of CA-SP1 cleavage. In clinical trials, BVM displayed good bioavailability and pharmacokinetic profiles (10). However, a high baseline BVM resistance was uncovered during the clinical trials among HIV-1 positive patients due to the polymorphism in the HIV-1 Gag region $(11,12)$. Therefore, it is important to study the possible drug resistance issue in the synthesis of BA derivatives as potential anti-HIV agent. A43D and BVM share the same BA scaffold (Figure 1). BVM possesses a dimethylsuccinic acid side chain at the $\mathrm{C} 3$ position, while $\mathrm{A} 43 \mathrm{D}$ has a long side chain modification at the $\mathrm{C} 28$ position (13). The BA entry inhibitors, such as A43D, do not have C3 side chain modifications but possess a relatively larger $\mathrm{C} 28$ side chain with 7 to 9 carbons to be optimal for their anti-entry activity. Thus, the objectives of this study are to synthesize new BA derivatives with improved microsomal stability and to investigate the effectiveness of the compounds not only to wild type HIV-1 but also the BVM-resistant variants.

It is clear that the HIV-1 Gag polymorphism greatly reduces the effectiveness of BVM. In light of the structural similarity between BVM and BA derivatives that inhibit HIV-1 entry, it is possible that HIV-1 variants with BVM resistant polymorphism could have an altered sensitivity to the BA entry inhibitors as well. Therefore, in addition to identifying new HIV-1 entry inhibitors with improved metabolic stability, their effectiveness against BVM resistant HIV-1 strains was also determined. As a result, 39 new BA derivatives with a variety of modifications at the $\mathrm{C} 28$ position were synthesized. Among them, compounds 1 10 have a BA scaffold with C28 modified with a 1, $\omega$-diamino alkane spacer and terminal Boc-masked amino acid $\left(\mathrm{R}^{\prime}\right)$. Compounds $\mathbf{1 1} \mathbf{- 2 8}$ are similar to the first ten compounds except that the spacers are $\omega$-aminoalkanoic acid that terminate with an ester of amino acid or aminoalkyl cyano moiety. The spacer length varied from 6 to 9 methylene groups as suggested by previous structure-activity relationship studies $(5,9,14,15)$. Compounds 29 37 contain new spacers such as a double bond, fluoride substituent, or oxygen atoms in contrast to those with methylene groups. Compounds $\mathbf{3 8}$ and $\mathbf{3 9}$ have the dihydrobetulinic acid scaffold with the same or similar C28 modification of $\mathbf{1 3}$.

The C-28 modified BA or dihydro-BA derivatives were synthesized using previously described methods (15). As shown in Scheme 1, BA 3-O-acetate was treated with oxalyl chloride and subsequently reacted with an alkyl di-amine or amino alkanoic acid ester in the presence of triethylamine to form an intermediate of BA with a C28 amide linker (2a, 4a, 8a, 11a-13a, 24a). The intermediate was hydrolyzed to remove the ester group(s) and then coupled with a boc-amino acid, amino acid ester, or aminoalkyl cyano reagent in the 
presence of $N, N^{\prime}$-dicyclohexylcarbodimide/hydroxybenzotriazole/triethylamine to form the final products $\mathbf{2}-\mathbf{2 8}$. Compounds $\mathbf{2 9}-\mathbf{3 7}$, which contain some unusual linkers at their C28 position such as ethylene glycol (PEG), fluoride substituted or unsaturated hydrocarbons, were also synthesized using a protocol similar to that described in Scheme 1. Compounds with a dihydro-BA scaffold, such as $\mathbf{3 8}$ and $\mathbf{3 9}$, were synthesized by the same methods applied for compounds $\mathbf{1 3}$ and $\mathbf{3 1}$ except dihydro-BA 3-O-acetate was used as the starting material.

\section{Anti-HIV activity of BA derivatives in single cycle infectivity assay}

The anti-HIV activities of the BA derivatives were initially evaluated in a single cycle HIV-1 infection assay with NL4-3 virus (Table 1) (15). This assay detects HIV-1 tatmediated luciferase production in TZM-bl cells after HIV-1 entry. Therefore, it is a convenient and effective assay for HIV-1 entry, but not maturation. The purpose of using this assay was to evaluate and identify new BA derivatives with potent anti-HIV entry activity. The results indicated that most of these new compounds displayed anti-HIV activities except for those compounds with PEG linkers $(\mathbf{3 3}$ - 37). The results indicated that saturated hydrocarbon linkers are better than less saturated side chains $(\mathbf{2 9}-\mathbf{3 2})$ for antiHIV-1 activity of these compounds. Previous studies have suggested that the optimal linker length of the $\mathrm{C} 28$ side chain is 8 methylene groups for BA derivatives to exhibit maximal activity $(5,15)$. The data of this study indicate that the optimal linker length to be 7 or 8 methylene groups for compounds with a $\mathrm{C} 28-\left(\mathrm{CH}_{2}\right) \mathrm{n}-\mathrm{NH}-\mathrm{COR}$ side chain $(\mathbf{1}-\mathbf{1 0})$, and 8 or 9 methylene groups for compounds with a $\mathrm{C} 28-\left(\mathrm{CH}_{2}\right) \mathrm{n}-\mathrm{CO}-\mathrm{NHR}$ side chain $(\mathbf{1 1}-\mathbf{2 8})$. A terminal glutamine group $(\mathbf{2}, \mathbf{5}, \mathbf{1 3}, \mathbf{1 5}, \mathbf{2 4}, \mathbf{3 8}$ and 39) is favored among a variety of amino acid residues (aa) investigated for the most effective anti-HIV-1 activity. None of the tested compounds were toxic to TZM-bl cells in the single-cycle assay at $4 \mu \mathrm{M}$.

\section{Anti-HIV activity of BA derivatives against BVM-resistant variant (V370A)}

In contrast to the discussed $\mathrm{C} 28$ modified BA derivatives with anti-HIV entry activities, it is known that the $\mathrm{C} 3$ modified BA derivative BVM [3-O-( $3^{\prime}, 3^{\prime}$-dimethylsuccinyl)-betulinic acid] does not inhibit HIV-1 entry. However, it is a potent HIV-1 maturation inhibitor. Phase II clinical trials revealed a high baseline drug resistance due to pre-existing polymorphisms at the QVT-motif (amino acid residues 369-371) within HIV-1 Gag SP1 $(12,16,17)$. Variation such as V370A, V370M, or V370 deletion resulted in high resistance to BVM, while deletion of T371 resulted in medium resistance to BVM $(18,19)$. The V370A polymorphism was found to be the most prevalent among HIV-1 positive patients $(18,19)$. We have constructed a panel of NL4-3 variants with BVM resistant genotypes (Figure 2).

The V370A variant was tested extensively in our study to evaluate anti-HIV activity of new BA derivatives against the BVM-resistant strain. We observed that BA derivatives 1 (A43D), 13 and $\mathbf{1 5}$ were 2- to 3-fold more potent against the resistant variant, while AZT was 2 times less potent against the resistant variant in a single cycle infection assay (Figure $3)$.

\section{Inhibition of HIV-1 and BVM-resistant variants by BA entry inhibitors in multiple-cycle replication assay}

To further evaluate the BA entry inhibitors on BVM-resistant HIV variants, the new BA derivatives were tested against a panel of HIV-1 variants with the V370A, $\triangle$ V370, or $\Delta \mathrm{T} 371$ genotype using the multi-cycle viral replication assay in MT4 cells. These resistant strains showed markedly decreased sensitivity to BVM when compared with the wild type NL4-3 (Table 2). Five synthesized compounds $(\mathbf{2}, \mathbf{1 3}, \mathbf{1 5}, \mathbf{3 8}$ and 39) were tested against 
HIV-1 NL4-3 and the resistant variants in the multi-cycle viral replication assay. The majority of the tested compounds were found to be at least 4-fold more potent against BVMresistant variants than the wild type NL4-3 (Table 2). The $\Delta \mathrm{V} 370$ and $\Delta \mathrm{T} 371$ variants were particularly sensitive to these entry inhibitors when compared to the V370A variant and were at least 5- to 10-fold more sensitive to the tested BA entry inhibitors when compared with the wild type NL4-3 virus. NL4-3 and the V370A variant were equally sensitive to the non-nucleoside HIV-1 RT inhibitor, TMC-278.

\section{In vitro metabolic stability of BA derivatives}

The five selected best entry inhibitors derived from BA $(\mathbf{2}, \mathbf{1 3}, \mathbf{1 5}, \mathbf{3 8}$ and 39$)$ were investigated for their microsomal stability using human liver microsomal preparations under oxidative conditions with a reference compound terfenadine. Terfenadine has a moderate-tofast half-life in vivo of around $3.5 \mathrm{~h}$. The results in Table 3 show that glutamine residue of the $\mathrm{C} 28$ side chain with Boc protected amine terminus (2) exhibited the fastest metabolism with $t_{1 / 2}$ of $18.92 \mathrm{~min}$. Leaving the glutamine terminus unprotected (39) did not significantly change its microsomal stability $\left(t_{1 / 2}: 24.75 \mathrm{~min}\right)$ when compared to A43D. The Benzyl ester protection of the glutamine terminus significantly improved microsomal stability of $\mathbf{1 5}$ with a $t_{1 / 2}$ of $41.01 \mathrm{~min}$ when compared to that of A43D ( $\left.t_{1 / 2}: 25.48 \mathrm{~min}\right)$ and terfenadine $\left(t_{1 / 2}\right.$ : $29.87 \mathrm{~min}$ ). In addition to the improved microsomal stability, compound 15 exhibited similar antiviral activity against NL4-3 and better activity against the BVM-resistant V370A variant when compared with A43D.

In summary, we have designed and synthesized 39 new BA derivatives with different C28 side chains. Among them, compounds 2, 13, 15, 38 and 39, carrying a glutamine terminus, showed potent anti-HIV activity with $\mathrm{EC}_{50}$ ranging from 0.04 to $0.12 \mu \mathrm{M}$ in a single cycle HIV-1 NL4-3 infection assay (Table 1). These BA entry inhibitors were in general more potent against the BVM-resistant variants than the wild type NL4-3 (Figure 2, Table 2). In addition, compounds $\mathbf{1 3}, \mathbf{1 5}$ and $\mathbf{3 8}$ showed improved metabolic stability in vitro when compared to the lead compound A43D. These results suggest that the new BA derivatives may serve as promising leads for further drug development against HIV-1.

\section{Supplementary Material}

Refer to Web version on PubMed Central for supplementary material.

\section{Acknowledgments}

This work was supported by the National Institute of Allergy and Infectious Diseases (NIAID) Grant AI-65310 awarded to C. H. Chen, The D. P. Bolognesi Award (Surgical Science, Surgery Department, Duke University) to L. Huang, and in part by Grant AI-077417 from NIAID awarded to K. H. Lee.

\section{Abbreviations}

$\begin{array}{ll}\text { BA } & \text { betulinic acid } \\ \text { LA } & \text { BVM, bevirimat } \\ \text { PEG } & \text { polyethylene glycol } \\ \text { Boc } & \text { tert-butoxycarbonyl } \\ \boldsymbol{t} \text {-Bu } & \text { tert-butyl } \\ \text { Bn } & \text { benzyl }\end{array}$




$$
\begin{array}{ll}
\text { Cpd } & \text { compound } \\
\text { AZT } & 3^{\prime} \text {-azido-3' }{ }^{\prime} \text {-deoxythymidine } \\
\text { EDC } & N \text {-(3-dimethylaminopropyl)- } N^{\prime} \text {-ethylcarbodiimide hydrochloride } \\
\text { THF } & \text { tetrahydrofuran } \\
\text { DCM } & \text { dichloromethane }
\end{array}
$$

\section{References and notes}

1. Tilton JC, Doms RW. Antiviral Res. 2010; 85:91. [PubMed: 19683546]

2. Sattentau QJ, Moore P. J Exp Med. 1991; 174:407. [PubMed: 1713252]

3. Kilby JM, Hopkins S, Venetta TM, DiMassimo B, Cloud GA, Lee JY, Alldredge L, Hunter E, Lambert D, Bolognesi D, Matthews T, Johnson MR, Nowak MA, Shaw GM, Saag MS. Nat Med. 1998; 4:1302. [PubMed: 9809555]

4. Lieberman-Blum SS, Fung HB, Bandres JC. Clin Ther. 2008; 30:1228. [PubMed: 18691983]

5. Soler F, Poujade C, Evers M, Carry JC, Hénin Y, Bousseau A, Huet T, Pauwels R, De Clercq E, Mayaux JF, Le Pecq JB, Dereu N. J Med Chem. 1996; 39:1069. [PubMed: 8676342]

6. Holz-Smith SL, Sun IC, Jin L, Matthews TJ, Lee KH, Chen CH. Antimicrob Agents Chemother. 2001; 45:60. [PubMed: 11120945]

7. Huang L, Lai W, Ho P, Chen CH. AIDS Res and Human Retroviruses. 2007; 23:28. [PubMed: 17263629]

8. Lai W, Huang L, Ho P, Li ZJ, Montefiori D, Chen CH. Antimicrob Agents Chemother. 2008; 52:128. [PubMed: 17954689]

9. Huang L, Ho P, Lee KH, Chen CH. Bioorg Med Chem. 2006; 14:2279. [PubMed: 16314103]

10. Smith PF, Ogundele A, Forrest A, Wilton J, Salzwedel K, Doto J, Allaway GP, Martin DE. Antimicrob Agents Chemother. 2007; 51:3574. [PubMed: 17638699]

11. Baelen KV, Salzwedel K, Rondelez E, Van Eygen V, De Vos S, Verheyen A, Steegen K, Verlinden Y, Allaway GP, Stuyver LJ. Antimicrob Agents Chemother. 2009; 53:2185. [PubMed: 19223634]

12. McCallister S, Lalezari J, Richmond G, Thompson M, Harrigan R, Martin D, Salzwedel K, Allaway G. Antivir Ther. 2008; 13:A10.

13. Kashiwada Y, Hashimoto F, Cosentino LM, Chen CH, Lee KHJ. Med Chem. 1996; 39:1016.

14. Huang L, Yuan X, Aiken C, Chen CH. AntimicrobAgents Chemother. 2004; 48:663.

15. Dang Z, Lai W, Qian K, Ho P, Lee KH, Chen CH, Huang LJ. Med Chem. 2009; 52:7887.

16. Adamson CS, Waki K, Ablan SD, Salzwedel K, Freed EO. J Virol. 2009; 83:4884. [PubMed: 19279107]

17. Van Baelen K, Salzwedel K, Rondelez E, Van Eygen V, De Vos S, Verheyen A, Steegen K, Verlinden Y, Allaway GP, Stuyver LJ. Antimicrob Agents Chemother. 2009; 53:2185. [PubMed: 19223634]

18. Margot NA, Gibbs CS, Miller MD. Antimicrob Agents Chemother. 2010; 54:2345. [PubMed: 20308382]

19. Adamson CS, Sakalian M, Salzwedel K, Freed EO. Retrovirology. 2010; 7:36. [PubMed: 20406463] 

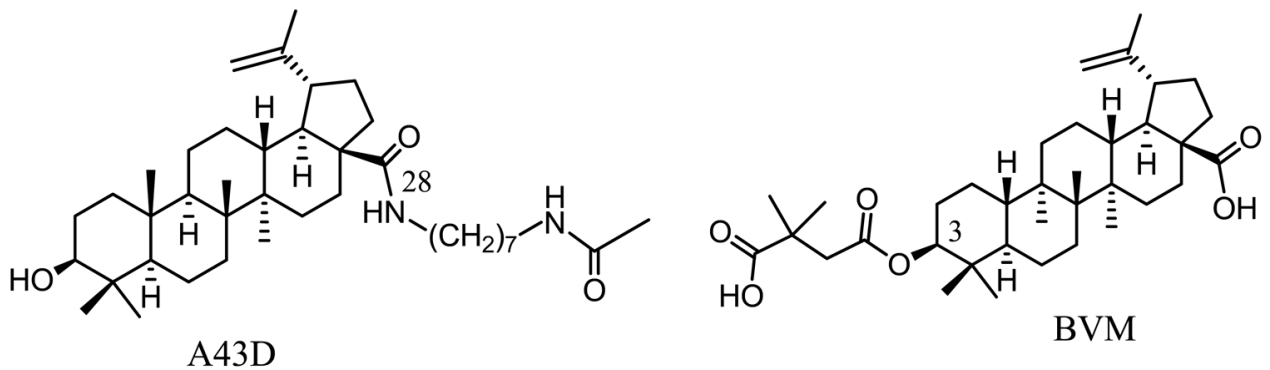

Figure 1.

Chemical structures of the BA derivatives A43D and Bevirimat. 


\begin{tabular}{l|r|c} 
Viruses & CA & SP1 \\
\hline & 363 & 369371 \\
\hline NL4-3 & V L & A E A M S Q V T N S A $\cdots$ \\
\hline NL4-3/V370 & V L & A E A M S Q $\triangle$ T N S A $\cdots$ \\
\hline NL4-3/V370A & V L & A E A M S Q A T N S A $\cdots$ \\
\hline NL4-3/T371 & V L & A E A M S Q V $\triangle$ N S A $\cdots$ \\
\hline
\end{tabular}

Figure 2. Genotype of three BVM-resistant variants

BVM-resistant variants (V370, V370A, and T371 ) were constructed from HIV-1 NL4-3 with mutations in the QVT motif of HIV-1 Gag (17). The symbol $\Delta$ denotes deletion of an amino acid. 


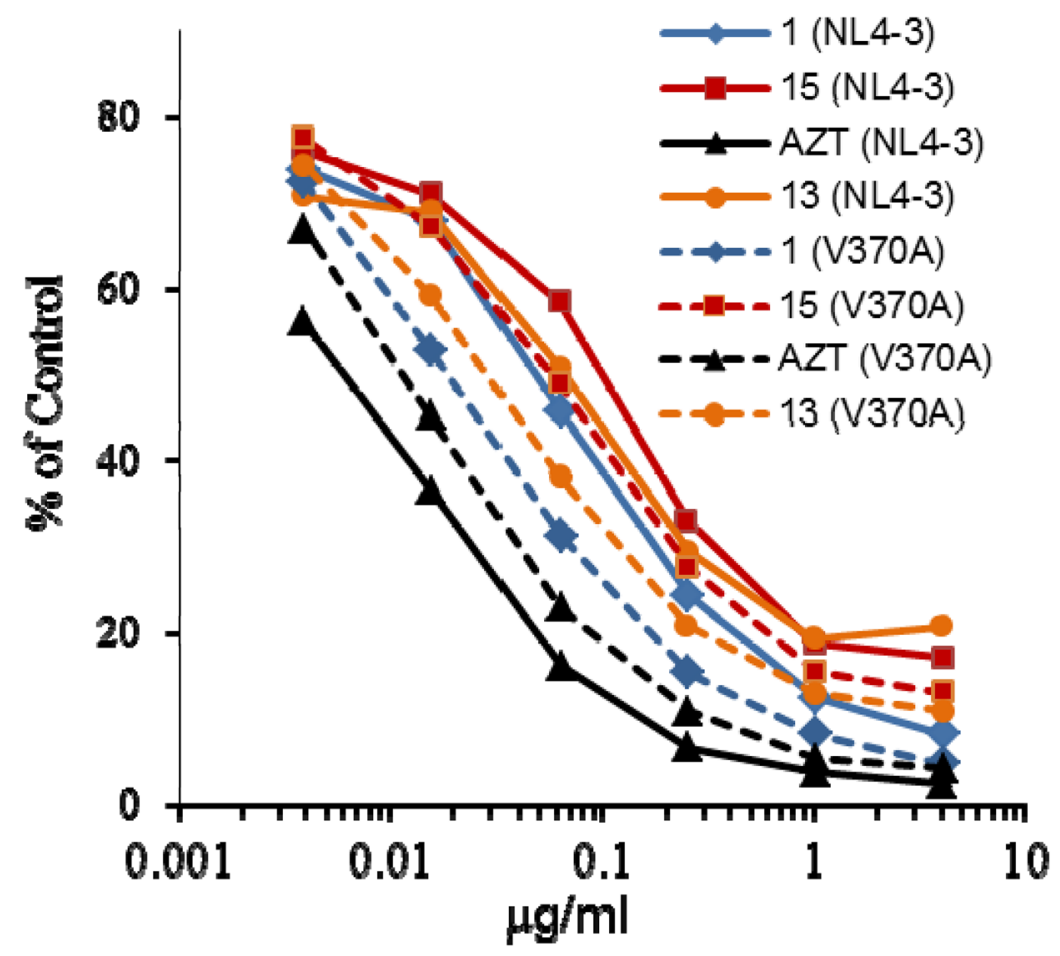

Figure 3. BVM-resistant HIV-1 variants were more sensitive to BA entry inhibitors Inhibition of HIV-1 infection was measured as the reduction in luciferase gene expression in TZM-bl cells after a single round of virus infection as described previously (15). The bevirimat sensitive virus HIV-1 NL4-3 (solid lines) and resistant virus NL4-3 V370A (dashed lines) were used in this assay. Control: HIV-1 NL4-3 or HIV-1 V370A infection, expressed as relative fluorescence units, in the absence of the compounds. 


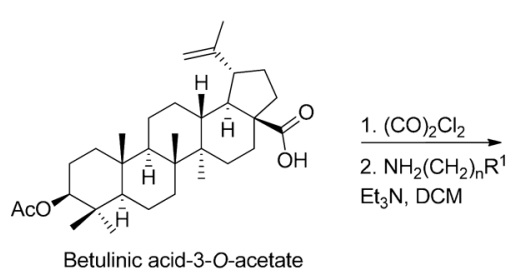

Betulinic acid-3-O-acetate

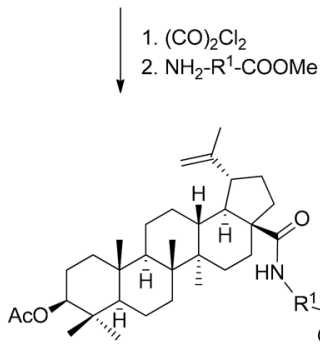

29a $\mathrm{R}^{1}=-\left(\mathrm{CH}_{2}\right)_{5} \mathrm{CH}=\mathrm{CH}$

30a $\mathrm{R}^{1}=-\left(\mathrm{CH}_{2}\right)_{5} \mathrm{CH}=\mathrm{CF}$

33a $\mathrm{R}^{1}=-\mathrm{PEG}_{2} \mathrm{CH}_{2}$

35a $\mathrm{R}^{1}=-\mathrm{PEG}_{2} \mathrm{C}_{2} \mathrm{H}_{4} \mathrm{NH}$

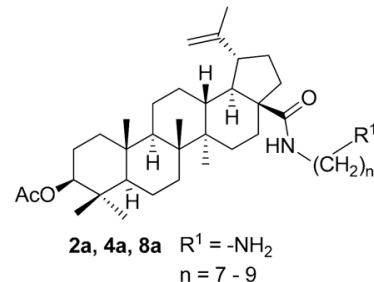

$n=7-9$

11a-13a, 24a $R^{1}=-C(=O) O B n$ $n=6-9$

1. $\mathrm{NaOH} / \mathrm{THF} / \mathrm{MeOH}$

2. $\mathrm{R}^{\prime} \mathrm{COOH}$ or $\mathrm{NH}_{2} \mathrm{R}^{\prime}, \mathrm{EDC}, \mathrm{Et}_{3} \mathrm{~N}$,

DCM

2 - $9 \mathrm{n}=7-9 \quad \mathrm{R}^{1}-\mathrm{R}^{2}=-\mathrm{NH}-\mathrm{AA}-\mathrm{Boc}$ $10 \mathrm{n}=8 \mathrm{R}^{1}-\mathrm{R}^{2}=-\mathrm{NH}-\mathrm{C}(=\mathrm{O})-\mathrm{CH}(\mathrm{NHBoc})-$ $\mathrm{C}_{2} \mathrm{H}_{4} \mathrm{CN}$

11 - $25 n=6$ - $9 \quad R^{1}-R^{2}=-C(=O)-A A$ esters $26 n=8 \quad R^{1}-R^{2}=-C(=O)-N^{2} H_{2} C N$

$27 \mathrm{n}=8 \quad \mathrm{R}^{1}-\mathrm{R}^{2}=-\mathrm{C}(=\mathrm{O})-\mathrm{NHC}_{2} \mathrm{H}_{4} \mathrm{CN}$

$28 \mathrm{n}=8 \quad \mathrm{R}^{1}-\mathrm{R}^{2}=-\mathrm{C}(=\mathrm{O})-\mathrm{N}(\mathrm{Me})-\mathrm{CH}_{2} \mathrm{CN}$

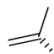

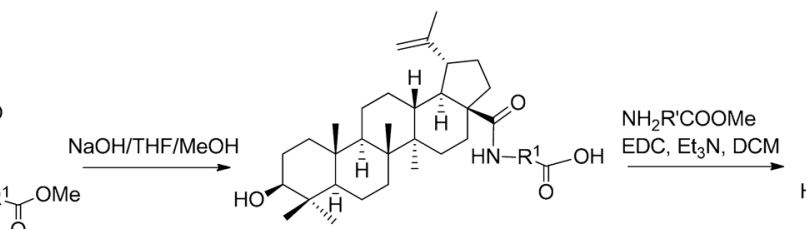

$29 \mathrm{R}^{1}=-\left(\mathrm{CH}_{2}\right)_{5} \mathrm{CH}=\mathrm{CH}$

$30 \mathrm{R}^{1}=-\left(\mathrm{CH}_{2}\right)_{5} \mathrm{CH}=\mathrm{CF}$

33b $\mathrm{R}^{1}=-\mathrm{PEG}_{2} \mathrm{CH}_{2}$

$35 \mathbf{b} \mathrm{R}^{1}=-\mathrm{PEG}_{2} \mathrm{C}_{2} \mathrm{H}_{4} \mathrm{NH}$

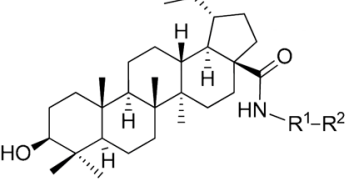

$\mathrm{NaOH}\left(31 \mathbf{b} \mathrm{R}^{1}=-\left(\mathrm{CH}_{2}\right)_{5} \mathrm{CH}=\mathrm{CH}-\mathrm{C}(=\mathrm{O})-\mathrm{Gly}-\mathrm{OMe}\right.$ $31 \mathrm{R}^{1}=-\left(\mathrm{CH}_{2}\right)_{5} \mathrm{CH}=\mathrm{CH}-\mathrm{C}(=\mathrm{O})$-Gly $\mathrm{NaOH}\left(\mathbf{3 2 b} \mathrm{R}^{1}=-\left(\mathrm{CH}_{2}\right)_{5} \mathrm{CH}=\mathrm{CF}-\mathrm{C}(=\mathrm{O})-\mathrm{Gly}-\mathrm{OMe}\right.$ $32 \mathrm{R}^{1}=-\left(\mathrm{CH}_{2}\right)_{5} \mathrm{CH}=\mathrm{CF}-\mathrm{C}(=\mathrm{O})$-Gly $\mathrm{NaOH}\left(33 \mathrm{c} \mathrm{R}^{1}=-\mathrm{PEG}_{2} \mathrm{CH}_{2} \mathrm{C}(=\mathrm{O})\right.$-Gly-OMe $\mathrm{NaOH}\left(33 \mathrm{R}^{1}=-\mathrm{PEG}_{2} \mathrm{CH}_{2} \mathrm{C}(=\mathrm{O})-\mathrm{Gly}\right.$ $34 \mathrm{c} \mathrm{R}^{1}=-\mathrm{PEG}_{2} \mathrm{CH}_{2} \mathrm{C}(=\mathrm{O})$-Ala-OMe $34 \mathrm{R}^{1}=-\mathrm{PEG}_{2} \mathrm{CH}_{2} \mathrm{C}(=\mathrm{O})-\mathrm{Ala}$ $35 \mathrm{R}^{1}=-\mathrm{PEG}_{2} \mathrm{C}_{2} \mathrm{H}_{4} \mathrm{NHC}(=\mathrm{O})-\mathrm{Me}$

$36 \mathrm{R}^{1}=-\mathrm{PEG}_{2} \mathrm{C}_{2} \mathrm{H}_{4} \mathrm{NHC}(=\mathrm{O})-\mathrm{CH}(\mathrm{Me})_{2}$ $37 \mathrm{R}^{1}=\mathrm{PEG}_{2}{ }_{\mathrm{O}}^{\mathrm{N}} \mathrm{NH}_{-} \mathrm{N}^{N}$

Scheme 1. Synthesis of betulinic acid derivatives 


\section{Table 1}

Inhibition of HIV-1 NL4-3 by BA entry inhibitors.
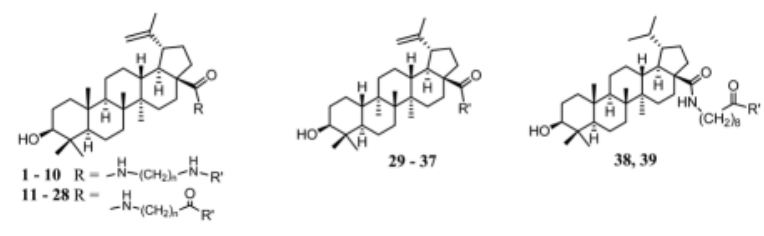

\begin{tabular}{|c|c|c|c|}
\hline Cpd & $\mathbf{n}$ & $\mathbf{R}^{\prime}$ & $\mathrm{EC}_{50}(\mu \mathrm{M})^{a}$ \\
\hline 1 & 7 & $-\mathrm{COCH}_{3}$ & 0.08 \\
\hline 2 & 7 & -Gln-NHBoc & 0.04 \\
\hline 3 & 7 & -Ala-NHBoc & 0.11 \\
\hline 4 & 8 & -Ala-NHBoc & 0.09 \\
\hline 5 & 8 & -Gln-NHBoc & 0.06 \\
\hline 6 & 8 & -Val-NHBoc & $2.43^{*}$ \\
\hline 7 & 8 & -Pro-NH-Boc & 0.16 \\
\hline 8 & 9 & -Gln-NHBoc & 0.12 \\
\hline 9 & 9 & -Ala-NHBoc & $>4^{*}$ \\
\hline 10 & 8 & & 0.08 \\
\hline
\end{tabular}

\begin{tabular}{|c|c|c|c|}
\hline 11 & 6 & -Gln-OMe & $>4^{*}$ \\
\hline 12 & 7 & -Gln-OMe & 0.14 \\
\hline 13 & 8 & -Gln-OMe & 0.09 \\
\hline 14 & 8 & -Gln-O-tBu & 0.14 \\
\hline 15 & 8 & -Gln-OBn & 0.12 \\
\hline 16 & 8 & -Asn-OMe & 0.11 \\
\hline 17 & 8 & -Glu-Di-OMe & 0.06 \\
\hline 18 & 8 & -Ala-OMe & 0.07 \\
\hline 19 & 8 & -Ile-OMe & 0.14 \\
\hline 20 & 8 & -Leu-OMe & 0.16 \\
\hline 21 & 8 & -Phe-OMe & $0.72^{*}$ \\
\hline 22 & 8 & -Pro-OMe & $0.16^{*}$ \\
\hline 23 & 8 & $-(O-\mathrm{tBu})-\mathrm{Thr}-\mathrm{OMe}$ & $3.49^{*}$ \\
\hline 24 & 9 & -Gln-OMe & 0.06 \\
\hline 25 & 9 & -Asn-OMe & 0.08 \\
\hline 26 & 8 & $-\mathrm{NHCH}_{2} \mathrm{CN}$ & $0.44^{*}$ \\
\hline 27 & 8 & $-\mathrm{NHC}_{2} \mathrm{H}_{4} \mathrm{CN}$ & $0.34^{*}$ \\
\hline 28 & 8 & $-\mathrm{N}(\mathrm{Me}) \mathrm{CH}_{2} \mathrm{CN}$ & $0.81^{*}$ \\
\hline
\end{tabular}



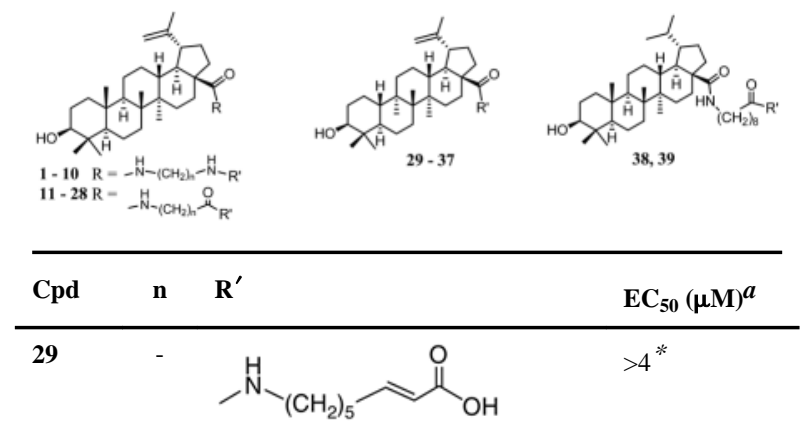

30<smiles>CNCCCCCCC(F)C(=O)O</smiles>

$>4^{*}$

31<smiles>CNCCC=CC(=O)NCC(=O)O</smiles>

0.15

32

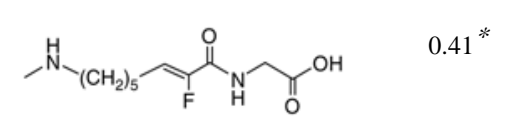

33

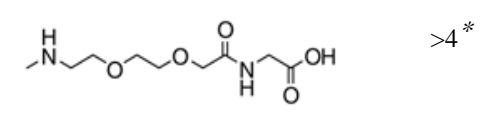

34

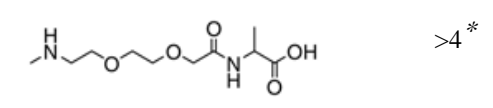

35

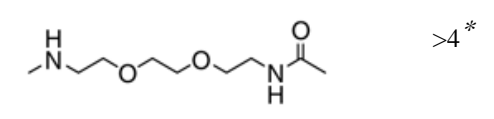

36<smiles>CNCCOCCOCCNC(=O)C(C)C</smiles>

37

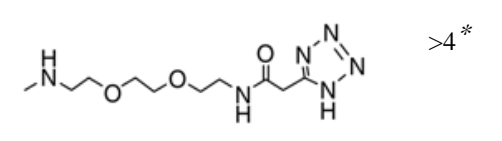

\begin{tabular}{llll}
38 & - & $-G l n-O M e$ & 0.05 \\
39 & - & $-G l n-O H$ & 0.04 \\
\hline
\end{tabular}

${ }^{a}$ Data is average of two independent experiments.

* Data from one experiment. 
